\title{
Impact of brief intervention and art therapy for alcohol users
}

\author{
Impacto da intervenção breve e arteterapia para usuários de álcool \\ Impacto de la intervención breve y de la arteterapia en usuarios de alcohol
}

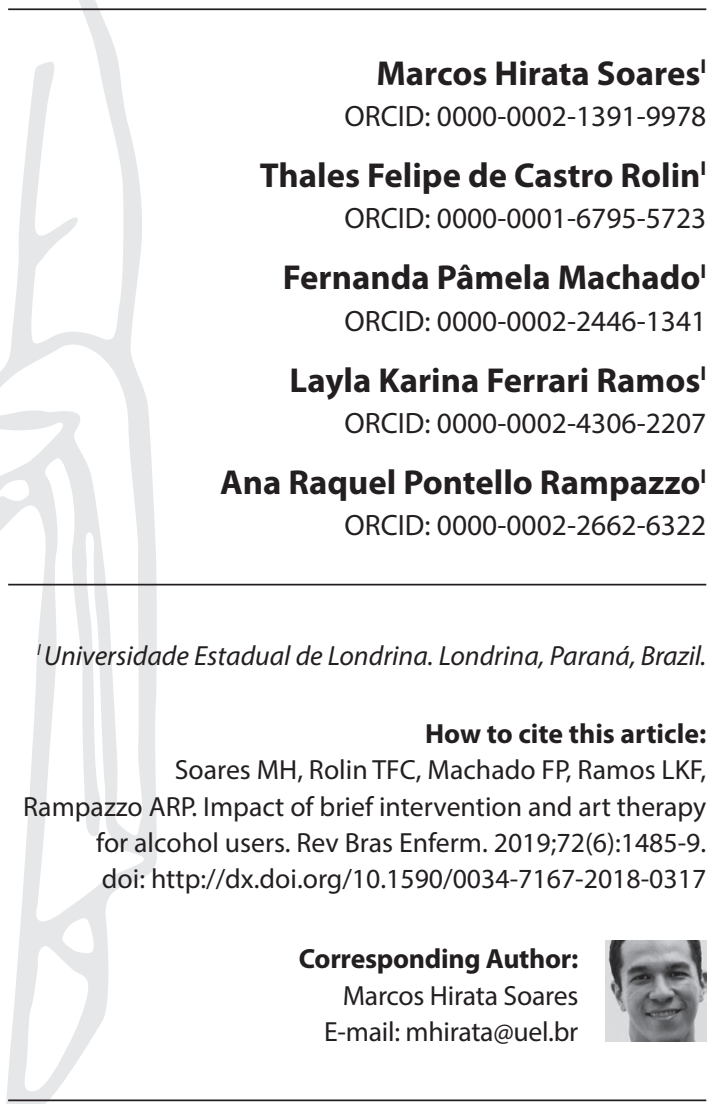

Submission: 03-09-2018
Approval: 04-26-2018

\begin{abstract}
Objective: To identify the impact of brief intervention paired with art therapy in patients who use alcohol. Method: This study presents intra-group design, with 11 alcoholics in the city of Tamarana-PR, Brazil, between 2015 and 2016. A test to identify the alcohol consumption level was used at the beginning/end of the actions. Cohen's effect size and paired t-test were used to identify the impact of the actions on the reduction of alcohol intake. Results: Six participants ceased alcohol consumption, four showed high level of consumption and one presented average consumption. The paired t-test result suggested statistically significant difference between the initial and final scores, as well as 0.76 effect size. Conclusion: The brief intervention associated with the art therapy resulted in significant impact in reducing alcohol consumption. Investing in the continuous training of primary health care professionals is crucial to consolidate the improvements achieved.

Descriptors: Alcoholism; Psycotherapy, Brief; Art Therapy; Psychiatric Nursing; Psychiatric
\end{abstract} Rehabilitation.

\section{RESUMO}

Objetivo: Identificar o impacto da intervenção breve em conjunto com a arteterapia em usuários que consomem álcool. Método: Delineamento intragrupo, com 11 alcoolistas na cidade de Tamarana-PR, entre 2015 e 2016. Foi utilizado um teste para identificação do nível de consumo de álcool ao início/término das ações e calculada a medida de efeito de Cohen e teste t pareado, para identificar o impacto das ações na redução do consumo de álcool. Resultados: Houve seis cessares do consumo de álcool, quatro apresentaram nível elevado de consumo e um apresentou consumo mediano. $\mathrm{O}$ resultado do teste $\mathrm{t}$ pareado sugeriu diferença estatisticamente significativa entre os escores iniciais e finais, assim como a medida de efeito de 0,76 . Conclusão: $A$ intervenção breve associada à arteterapia resultaram em grande impacto para a redução do consumo de álcool. É fundamental investir na educação continuada dos profissionais da atenção primária em saúde para consolidar as melhorias obtidas.

Descritores: Alcoolismo; Psicoterapia Breve; Terapia pela Arte; Enfermagem Psiquiátrica; Reabilitação Psiquiátrica.

\section{RESUMEN}

Objetivo: Evaluar el impacto de la intervención breve junto con la arteterapia en usuarios que consumen alcohol. Método: Diseño intragrupo, siendo realizado entre 2015 y 2016, con la participación de 11 alcohólicos de la ciudad de Tamarana (PR, Brasil). Se realizó una prueba para identificar el nivel de consumo de alcohol antes y después de las acciones, $y$ se calcularon el tamaño del efecto de Cohen y la prueba t pareada para evaluar el impacto de las acciones en la reducción del consumo de alcohol. Resultados: Seis dejaron de consumir alcohol, cuatro presentaron un alto consumo y uno presentó un consumo mediano. El resultado de la prueba t pareada reveló una diferencia estadísticamente significativa entre los puntajes inicial y final, así como en el tamaño del efecto con un 0,76 . Conclusión: La intervención breve asociada a la arteterapia tuvo un gran impacto en la disminuición del consumo de alcohol. Es fundamental invertir en la educación continuada de los profesionales de la atención primaria de salud para consolidar las mejoras obtenidas.

Descriptores: Alcoholismo; Psicoterapia Breve; Terapia con Arte; Enfermería Psiquiátrica; Rehabilitación Psiquiátrica. 


\section{INTRODUCTION}

Alcoholism is the term that has been used to define this medical condition as a multifactorial syndrome, caused by high levels of alcohol intake, associated with the strong desire to ingest the substance with physical, mental and social impairments ${ }^{(1)}$. According to the World Health Organization (WHO), alcohol is the most consumed psychoactive substance in the world. Worldwide, the harmful use of alcohol causes about of 3.3 million deaths per year, requiring the investment in strategies for the prevention of alcoholism, especially in public health services ${ }^{(2)}$.

One of the strategies that can be highlighted due to its effectiveness and relative low cost is the technique called Brief Intervention (BI), which was developed in Canada by Sanchez-Craig in 1972, and is based on behavioral psychology. Brief intervention was created as a therapeutic approach to alcohol-dependent patients, seeking to stimulate the interruption or decrease in the consumption of alcohol and/or other drugs. Currently, BI presents techniques and strategies that can vary according to the professional who will apply it, as well as its duration, goals and application context $\mathrm{t}^{(3-5)}$. After the consolidation of $\mathrm{BI}$ as an effective technique, a meta-analysis found that it reduced mortality rates between 23 to $36 \%$ of users of large quantities of alcohol ${ }^{(6)}$. The effects of the application of this technique suggest that it is useful in public health practice to prevent the harmful use of alcohol by young people and adults, as well as to reduce damage that have already affected patients.

The literature suggests that there is an immediate reduction in alcohol consumption among patients with severe dependence; thus, improving their health when compared to a similar sample of patients without treatment ${ }^{(7)}$. In general, BI presents an educational and motivational approach, in which the main goal is to trigger the decision and commitment of patients towards change to reduce the risk of damage caused by excessive alcohol consumption ${ }^{(8-10)}$.

Although some authors have developed studies using $\mathrm{BI}$ in emergency and ambulatory services, they concluded that this technique is more effective in primary care since the individual is not in an advanced stage of chemical dependency ${ }^{(7-9)}$.

In 2008, a study conducted for six months with approximately 326 alcohol addicted individuals and non-addicts, proved that both groups have benefited from Bl interventions, reaching significant levels of reduction of total beverage ingested and in the number of days of consumption ${ }^{(9)}$. Moreover, another study showed that using criteria established by the WHO (cost-effectiveness below the country's per capita gross domestic product), the incorporation of a motivational intervention with alcoholic patients is highly cost-effective ${ }^{(10)}$.

From brief intervention's perspective, an individual who abuses alcohol use is a human being facing a situation of physical and emotional discomfort, who requires care from professionals - e.g., from a nurse - who can have an empathic understanding stance and not be judgmental, as well as having a holistic understanding of the individual. Art therapy is thus capable of creating a positive environment for self-knowledge, for the expression of ideas or feelings and to facilitate their creative expression through $\operatorname{art}^{(11)}$. Art therapy channels the individual's mental restructuring and reorganization effort, being focused on the subjective and particular processes of each person ${ }^{(11-13)}$.
There are few studies on the use of $\mathrm{BI}$ paired with another method, given that the transformative potential of art therapy integrated with BI has been hypothesized previously ${ }^{(14)}$; moreover, there are very few studies in which the professional who performs the $\mathrm{BI}$ is a nurse since this technique has been applied mostly by psychologists and other mental health professionals, thus justifying the importance of this study, since the psychiatric nurse has compatible training and skills to perform this technique ${ }^{(15-16)}$.

\section{OBJECTIVE}

To evaluate the impact of brief intervention paired with art therapy.

\section{METHOD}

\section{Ethical aspects}

The executors of actions were a psychiatric nurse and an undergraduate nursing student, both linked to the academic university extension project. They were trained to conduct the IB based on the contents of a university extension course of great thematic relevance ${ }^{(17)}$. They were also trained in the implementation of mosaic workshops.

The study was conducted in the city of Tamarana-PR, Brazil. According to data from the Brazilian Institute of Geography and Statistics (IBGE), the population of the municipality is estimated in 13,939 inhabitants and the human development index (HDI) is $0.621^{(18)}$, with $42.42 \%$ incidence of poverty and average income of two minimum wages per month. The study population was composed of 11 subjects identified with abusive consumption of alcohol and who participated in the "Social inclusion project for people with drug-related problems" (Projeto de inclusão social de pessoas com problemas decorrentes de drogas), after approval by the Research Ethics Committee on Human Beings of Universidade Estadual de Londrina. The study was conducted in the period of one year, starting in September 2015 and ending in September 2016. The inclusion criterion was to undergo the Alcohol Use Disorder Identification Test (AUDIT) and present $a \geq 16$ score. The subjects identified with the required score received the $\mathrm{Bi}$ and, subsequently, the appropriate information regarding the participation in the project ${ }^{(19-20)}$.

\section{Study design, location and period}

This is an intra-group study in which the measurements are compared in a single group of participants, usually in two different time periods, proposed as a method for the evaluation of the change that occurred with the impact of certain actions on the subjects ${ }^{(21)}$. The guidelines from the STROBE Statement were used to present the information of this study, partially because this study is an intra-group design, i.e., it does not have all the characteristics of a clinical trial to be framed by CONSORT.

From this point on, the participants began their activities of the project, which consisted of art therapy workshops using the mosaic technique, the implementation of AUDIT and the BI. The patients participated for 10 months, engaging in workshops for 
3 hours per week. The first two months were used for identifying the cases and training the researchers. The identification of patients by the AUDIT and initial application of BI were conducted in the two months prior to the start of the workshops. It must be noted that brief intervention as proposed ${ }^{(3,6,8)}$ was applied in the first and final meetings. The workshops were conducted over the course of the project to strengthen behavioral change. In addition to the activities offered, patients continued their routine follow-up on the Basic Health Unit (UBS), receiving care from specialized doctors.

One of the main advantages of $\mathrm{Bl}$ is being brief, showing good cost-benefit ratio when compared to longer interventions. Moreover, it can be an interesting proposal for alcohol abuse prevention and as well as being implemented in work environments, although it requires specific attention in any context. Brief intervention must enable critical reflection to psychologists, human resource professionals and other individuals involved, since the focus is to motivate the user to change their use of drugs ${ }^{(10)}$.

This is a structured intervention strategy, focal and objective, with technical procedures that allow studies on its effectiveness. Its goal is to help in the development of the autonomy of individuals, giving them the ability to take the initiative and responsibility for their choices. The term BI refers to a care strategy with limited time and focused on the patient's behavior change $\mathrm{e}^{(6-8,10)}$.

Art therapy consists of the application of expressive artistic techniques, based on certain psychological theories, whose objective is the reorganization of the patient's psychic state; thus, covering various psychological states that indirectly reflect the mental health, which assists in therapeutic processes by promoting psychological recovery ${ }^{(11-13)}$. Among the various expressive techniques, tiled mosaic presents a symbolic link to the process of death, namely, deconstruction and reconstruction, representing the psychosocial rehabilitation process of drug-or alcohol-dependent patients considering a Harm Reduction perspective ${ }^{(13-14)}$.

\section{Sample}

An active search was held in the UBS of the city of Tamarana$\mathrm{PR}$, to present the project and conduct the initial application of AUDIT and BI. The search identified 32 patients and they were all invited to participate in the project's activities. On the day scheduled for the start, 11 patients attended the meeting. After the project's activities, duration and goals were explained, all agreed to participate.

\section{Data analysis}

Brief Intervention was applied in two moments; one prior to the start of the art therapy workshops, and one after the art therapy interventions had ended. The mean value between the initial and final AUDIT score was calculated, and compared by paired t-test. Effect size was obtained by Cohen's $r^{(22)}$.

\section{RESULTS}

The study population was composed of seven males, aged between 34 to 45 years, of whom six lived in the rural area of the municipality, eight lived with a spouse and six had no stable income. Six patients ceased the use of alcohol in re-evaluation after the use of the BI technique. Of the 11 participants in total, four presented high level of consumption and one an average score.

Table 1 - Sociodemographic characterization, initial and final AUDIT scores after participating in brief intervention and art therapy, Tamarana, Paraná, Brazil, 2016

\begin{tabular}{|c|c|c|c|c|c|c|c|}
\hline Subject & Age & Sex & $\begin{array}{l}\text { Affective } \\
\text { company }\end{array}$ & $\begin{array}{l}\text { Place of } \\
\text { residence }\end{array}$ & Income & $\begin{array}{c}\text { AUDIT } \\
\text { (initial) }\end{array}$ & $\begin{array}{l}\text { AUDIT } \\
\text { (final) }\end{array}$ \\
\hline 1 & 37 & M & No & Urban & No & 39 & 26 \\
\hline 2 & 48 & M & Yes & Urban & Yes & 29 & 30 \\
\hline 3 & 35 & $\mathrm{~F}$ & Yes & Rural & No & 28 & 00 \\
\hline 4 & 34 & M & Yes & Urban & Yes & 27 & 27 \\
\hline 5 & 38 & $\mathrm{~F}$ & Yes & Rural & No & 27 & 00 \\
\hline 6 & 44 & M & No & Rural & No & 27 & 00 \\
\hline 7 & 43 & $\mathrm{~F}$ & Yes & Urban & Yes & 22 & 15 \\
\hline 8 & 58 & $M$ & Yes & Rural & No & 21 & 00 \\
\hline 9 & 58 & M & Yes & Rural & No & 19 & 00 \\
\hline 10 & 45 & $\mathrm{~F}$ & Yes & Urban & Yes & 19 & 25 \\
\hline 11 & 64 & M & No & Urban & Yes & 16 & 00 \\
\hline
\end{tabular}

The result of the paired t-test calculation indicated that there is statistical significance when comparing to the initial mean (24.9) and standard deviation (6.41) of the AUDIT score to the final mean (11.18) and standard deviation (13.34). In other words, from the first contact to the end of the patient's treatment $(T=3.74 ; p<$ 0.01 ), there is difference in the mean scores. Effect size calculation by Cohen's $r$ resulted in a $r=0.76$ score, which characterizes the importance of the practice as great ${ }^{(22)}$.

\section{DISCUSSION}

The sociodemographic characteristics such as marital status, sex and age corroborated the characteristics of current studies ${ }^{(2-3,6-7,10)}$, reflecting the prevalent profile of alcohol users, thus allowing the findings of this study to be inferred and generalized.

A study on the sensitization and awareness-raising of the risks of high alcohol intake in 370 inpatients ${ }^{(23)}$ suggests that approaching alcohol users under hospitalization is effective in $84 \%$ of cases. However, patients older than 60 years and with positive AUDIT results demonstrated reduced ability to accept or discuss the problems with alcohol, while adolescents took such discussion as a valid one ${ }^{(24)}$.

The impact of BI was verified through statistical analysis by paired t-test, although this technique has already been established and proven. Several meta-analysis studies concluded that a single intervention and verification after six months was able to more effectively reduce the consumption of drugs, when compared to the simple technique of orientation ${ }^{(5-8,10,20,23)}$. As discussed in a systematic review ${ }^{(25)}$ and in another studies on the findings using art therapy ${ }^{(26-27)}$, both suggest the adoption of standardized methods for the evaluation of results. This study thus generated a highly generalizable measure of comparison, enabling subsequent studies.

A study on cost-effectiveness ${ }^{(10)}$ suggests that professionals who seek maximum impact with minimum resources should direct their efforts towards the use of short and simple interventions 
that focus on inciting individuals to recognize their alcohol intake, considering that such interventions are probably more effective in alcoholic middle-aged men. Other authors also suggest that the application of screening instruments with feedback can be effective for reducing alcohol intake, including in emergency services $^{(5,8-9,24,28)}$.

Although this study has found the impact of BI paired with art therapy practice, and considering that this study was conducted as an academic project supported by a funding agency, a meta-analysis study done with randomized clinical trials ${ }^{(28)}$ confirms the need for researchers to continue the project but focusing on permanent education in health, since the cited study found that BI contributes to the adhesion to treatment. With regard to alcohol users, the positive results of the interventions occur quickly but are only guaranteed when continuous and long-term actions are implemented. Alcoholism is a chronic disease that requires continuous monitoring, i.e., the Primary Health Care system of each municipality must continue the improvements obtained with the project's actions so BI can achieve its objective more appropriately ${ }^{(8,20,24)}$.

\section{Study limitations}

This study could not be compared to other experiences since no studies evaluating the impact of $\mathrm{BI}$ paired with another complementary health practice were found. Future studies may include proposals for community trials, which could promote an analysis in a controlled environment, although this method is not entirely possible in this type of intervention ${ }^{(26-27)}$.

\section{Contributions to the field of nursing}

Brief intervention associated with the offer of art therapy - in the technique of mosaic - reinforces the need to provide psychological support for alcoholic patients since the art therapy workshops enabled the creation of a holistic environment for experiencing conflicts, difficulties and anxieties with a smaller burden of suffering, contributing to the rehabilitation of the patients' mental disorder ${ }^{(11-13)}$, in addition to being an environment that promotes social reintegration by approaching people with similar problems ${ }^{(20)}$. From the interpretation of the scores obtained, the welcoming atmosphere created by art therapy implied moving beyond the therapeutic environment proposed by $\mathrm{BI}$.
Considering that from 2017 art therapy became part of the list of integrative and complementary care practices, based on Ordinance No. 145 of January 11, 2017 of the Brazilian Ministry of Health ${ }^{(29)}$, nurses must be capable of appropriating such practices, as well as having knowledge about the impact of these changes on health outcomes; thus, making this a pioneering study on the proposed theme and contributing to the improvement of the health conditions of alcoholic patients.

\section{CONCLUSION}

This study found that BI paired with art therapy presented a high effectiveness degree in the reduction/cessation of abusive alcohol intake, suggesting that, at least, the art therapy is not opposed to the objectives of BI since the effect size obtained was significant, thus indicating the importance of an integrated approach caring for individuals who make abusive use of alcohol. The few Brazilian experiences of nurses who conducted studies using $\mathrm{BI}$ can be pointed as a limitation. Despite this limitation, our results showed that psychiatric nurses are capable to perform this technique with great results.

The implementation of several care fronts for individuals who abuse alcohol in the primary care network, as discussed in this study, subsidize a proper care and effective aid to this patient, which was confirmed by the large number of individuals who ceased alcohol use. However, larger studies on the recurrence of use after the care action ends and the patient returns to his/ her family and to social coexistence are required.

This specialized care service demands the continuous training of those involved, demonstrating the importance of permanent education in health of professionals working in primary care, so they can continue to provide the benefits obtained by the actions conducted. In this sense, subsequent studies can analyze the capacity of psychiatric nurses to collaborate with and support other colleagues, such as primary care nurses, so they can continue the actions, especially when considering that art therapy is part of the integrative and complementary care practices.

\section{FUNDING}

Department of Science, Technology and Higher Education of Paraná/University Without Borders Program, SETI-PR.

\section{REFERENCES}

1. Siqueira MM, organizador. Álcool, tabaco e outras drogas na atenção básica. Vitória: Edufes; 2016.

2. Word Health Organization (WHO). Global status on alcohol and health [Internet]. Geneva: WHO; 2014 [cited 2018 Aug 23]. Available from: https://apps.who.int/iris/bitstream/handle/10665/112736/9789240692763_eng.pdf

3. McCambridge J, Cunningham JA. The early history of ideas on brief interventions for alcohol. Addiction. 2014;109(4):538-46. doi: 10.1111/ add. 12458

4. Silva EC, Tucci AM. Intervenção breve para redução do consumo de álcool e suas consequências em estudantes universitários brasileiros. Psicol Reflex Crit. 2015;28(4):728-36. doi: 10.1590/1678-7153.201528410

5. Schmidt CS, Schulte B, Seo H-N, Kuhn S, O'Donnell A, Kriston L, et al. Meta-analysis on the effectiveness of alcohol screening with brief interventions for patients in emergency care settings. Addiction. 2016;111(5):783-94. doi: 10.1111/add.13263

6. Platt L, Melendez-Torres GJ, O’Donnell A, Bradley J, Newbury-Birch D, Kaner E, et al. How effective are brief interventions in reducing alcohol 
consumption: do the setting practitioner group and content matter? Findings from a systematic review and metagression analysis. BMJ Open. 2016;6(8):e011473. doi: 10.1136/bmjopen-2016-011473

7. Grant S, Pedersen ER, Osilla KC, Kulesza M, D'Amico EJ. Reviewing and interpreting the effects of brief alcohol interventions: comment on a Cochrane review about motivational interviewing for young adults. Addiction. 2016;111(9):1521-7. doi: 10.1111/add.13136

8. Pereira MO, Anginoni BM, Ferreira NC, Oliveira MAF, Vargas D, Colvero LA. Efetividade da intervenção breve para o uso abusivo de álcool na atenção primária: revisão sistemática. Rev Bras Enferm [Internet]. 2013;66(3):420-8. doi: 10.1590/\$0034-71672013000300018

9. Schmidt CS, Schulte B, Seo H-N, Kuhn S, O'Donnell A, Kriston L, et al. Meta-analysis on the effectiveness of alcohol screening with brief interventions for patients in emergency care settings. Addiction. 2015;111(5):783-94. doi: 10.1111/add.13263

10. Shepard DS, Lwin AK, Barnett NP, Mastroleo N, Colby SM, Gwaltney C, et al. Cost-effectiveness of motivational intervention with significant others for patients with alcohol misuse. Addiction. 2016;111(5):832-9. doi: 10.1111/add.13233

11. Kim H, Kim S, Choe K, Kim JS. Effects of mandala art therapy on subjective well-being, resilience, and hope in psychiatric inpatients. Arch Psychiatr Nurs. 2018;32(2):167-73. doi: 10.1016/j.apnu.2017.08.008

12. Chung S. Study on the effectiveness of a mandala meditation program for improving the psychotic symptoms of schizophrenics. Kor J Art Ther. 2016;23(4):1763-82.

13. Kim H-K, Kim KM, Nomura S. The effect of group art therapy on older Korean adults with neurocognitive disorders. Arts Psychother. 2016;47(7):48-54. doi: 10.1016/j.aip.2015.11.002

14. Coqueiro NF, Vieira FRR, Freitas MMC. Art therapy as a therapeutic tool in mental health. Acta Paul Enferm. 2010;23(6):859-62. doi: 10.1590/ S0103-21002010000600022

15. Santos SSC, Nóbrega MML. Teoria das relações interpessoais em enfermagem de Peplau: análise e evolução. Rev Bras Enferm. 1996;49(1):5564. doi: 10.1590/S0034-71671996000100007

16. Souza J, Kantorski LP, Luis MAV, Oliveira NF. Mental health interventions to treatment of drugs'abusers patients: policies, practices and documentation. Texto Contexto Enferm. 2012;21(4):729-38. doi: 10.1590/S0104-07072012000400002

17. Formigoni MLOS, coordenadora. Módulo 4: Intervenção Breve [Internet]. Brasília: Secretaria Nacional de Políticas sobre Drogas; 2014 [citado 2018 ago. 23]. Available from: http://www.supera.senad.gov.br/wp-content/uploads/2016/03/SUP7_Mod4.pdf

18. Instituto Brasileiro de Geografia e Estatística (IBGE). Cidades [Internet]. 2016 [cited 2016 Dec 20]. Available from: https://cidades.ibge.gov.br/ brasil/pr/tamarana/panorama

19. Ferreira ML, Albertoni MR, Silva NB, Sartes LMA. Avaliação da efetividade da Intervenção Breve para a prevenção do uso de álcool no trabalho. Psicol Pesqui. 2016;10(1):34-43. doi: 10.24879/201600100010045

20. O'Donnell A, Anderson P, Newbury-Birch D, Schulte B, Schmidt C, Reimer J, et al. The impact of brief alcohol interventions in primary healthcare: a systematic review of reviews. Alcohol Alcohol. 2014;49(1):66-78. doi: 10.1093/alcalc/agt170

21. Hulley SB, Cummings SR, Browner WS, Grady DG, Newman TB. Delineando a pesquisa clínica: uma abordagem epidemiológica. $3^{a}$ ed. Porto Alegre: Artmed; 2008.

22. Rosnow RL, Rosenthal R, Robin DB. Contrasts and correlations in effect size estimation. Psychol Sci. 2000;11(6):446-53. doi: 10.1111/1467-9280.00287

23. Broyles $\mathrm{LM}$, Rosenberger R, Hanusa BH, Kraemer KL, Gordon AJ. Hospitalized patient's acceptability of nurse delivered screen and referral to treatment. Alcohol Clin Exp Res [Internet]. 2012 [cited 2017 Feb 7];36(4):725-31. Available from: https://www.ncbi.nlm.nih.gov/pubmed/22250713

24. Cunha SM, Carvalho JCN, Kolling NM, Silva CR, Kristensen CH. Social skills in alcoholics: an exploratory study. Rev Bras Ter Cogn. 2007;3(1):31-9. doi: 10.5935/1808-5687.20070004

25. Glass JE, Hamilton AM, Powell BJ, Perron BE, Brown RT, Ilgen MA. Specialty substance use disorder services following brief alcohol intervention: a meta-analysis of randomized controlled trials. Addiction. 2015;110(9):1404-15. doi: 10.1111/add.12950

26. Slayton CS, D'Archer J, Kaplan F. Outcome studies on the efficacy of art therapy: a review of findings. Art Ther [Internet]. 2010 [cited 2018 Apr 24];27(3):108-18. Available from: https://files.eric.ed.gov/fulltext/EJ901216.pdf

27. Lith TV. Art therapy in mental health: a systematic review of approaches and practices. Arts Psychother. 2016;47:9-22. doi: 10.1016/j.aip.2015.09.003

28. Elzerbi C, Donoghue K, Boniface S, Drummond C. Variance in the efficacy of brief interventions to reduce hazardous and harmful alcohol consumption between injury and noninjury patients in emergency departments: a systematic review and meta-analysis of randomized controlled trials. Ann Emerg Med. 2017;70(5):714-23. doi: 10.1016/j.annemergmed.2017.05.004

29. Ministério da Saúde (BR). Portaria n 849, de 24 de março de 2017. Inclui a Arteterapia, Ayurveda, Biodança, Dança Circular, Meditação, Musicoterapia, Naturopatia, Osteopatia, Quiropraxia, Reflexoterapia, Reiki, Shantala, Terapia Comunitária Integrativa e Yoga à Política Nacional de Práticas Integrativas e Complementares. Diário Oficial da União, Brasília, 27 mar. 2017 [Internet]. Brasília; 2017 [cited 2018 Apr 24]. Available from: http://bvsms.saude.gov.br/bvs/saudelegis/gm/2017/prt0849_28_03_2017.html 